\title{
PENGARUH KUALITAS LAYANAN DAN KEPERCAYAAN TERHADAP KEPUASAN PELANGGAN PRODUK FASHION PADA ONLINE SHOP YELLOW FACY JEANS MELALUI MEDIA SOSIAL INSTAGRAM
}

\author{
Nadya Imanda ${ }^{1)}$ \\ 1) Mahasiswa Program Studi Manajemen FE UNKRIS \\ Nuridin ${ }^{2)}$ \\ 2) Dosen Program Studi Manajemen FE UNKRIS \\ Alamat: Kampus UNKRIS, Jatiwaringin Jakarta Timur \\ Email : h.nuridin58@gmail.com
}

\begin{abstract}
The purpose of this research is to know the influence of Service Quality, Trust and Consumer Satisfaction of fashion product at online shop "Yellow Facy Jeans" through social media social instagram. This research was conducted on Yellow Facy Jeans customer in Bekasi Timur in 2017. The method used in this research is non-probability through quota sampling procedure with total sample of 120 respondents. Data collection techniques with questionnaires distributed from a total of 165 subscribes minus 40 customers who did not meet the criteria and the rest 5 customers did not answer the question completely so it could not be tested. The results showed that (1) the F test of Service Quality $\left(X_{1}\right)$ and Trust $\left(X_{2}\right)$ against Consumer Satisfaction Yellow Facy Jeans $(Y)$ shows that Quality of Service and Trust simultaneously have a significant effect on Consumer Satisfaction in Yellow Facy Jeans; (2) the effect of Service Quality partially on Yellow Facy Jeans Consumer Satisfaction through t test showing sig value of 0,000 < 0,05, which means partial Service Quality significantly influence Consumer Satisfaction on Yellow Facy Jeans ; and (3) the partial influence of Trust on Yellow Facy Jeans Consumer Satisfaction is tested by t test showing sig value of $0,000<0,5$, which means partial Trust has significant effect on Consumer Satisfaction in Yellow Facy Jeans.
\end{abstract}

Keywords : Service quality, trust, consumer satisfaction

\section{PENDAHULUAN}

Teknologi zaman sekarang jauh lebih canggih dibandingkan dengan zaman dahulu. Transaksi jual beli pada zaman dahulu adalah dengan menggunakan sistem barter. Barter adalah kegiatan tukar-menukar barang yang terjadi tanpa perantaran uang, dimana penjual dan pembeli bertukar barang sesuai dengan kebutuhannya. Melalui kesepakatan bersama, kemudian penjual dan pembeli bertemu secara langsung untuk melakukan transaksi. Internet pada saat ini memudahkan transaksi jual beli masyarakat berbagai kalangan dari kalangan muda hingga tua.
Internet membuka kesempatan untuk bisnis baru dimana transaksi-transaksi bisnis kini semakin banyak dilakukan dengan melalui media elektronik. Teknologi yang telah berkembang saat ini membuka mata dunia akan sebuah kehidupan tanpa batas dimana transaksi jual beli dapat dilakukan secara online melalui internet. Pengaruh dari berkembangnya teknologi melalui internet yaitu merubah gaya hidup primitif menuju gaya hidup yang lebih modern serta dengan adanya internet menjadikan masyarakat kecenderungan dan ketergantungan beraktivitas pada dunia maya.

Berbelanja secara online mulanya hanya dapat dilakukan oleh wanita atau 
pria yang memiliki pendapatan dan pendidikan tinggi. Namun hal itu tidak terjadi lagi pada saat ini, karena kemudahan jangkauan dan transaksi yang ditawarkan oleh online shop dapat menarik banyak pelanggan tanpa adanya perbedaan status sosial maupun gender. Kegiatan berbelanja tidak lagi menjadi kegiatan yang direncanakan, dimana pelanggan tidak perlu mengunjungi pusat perbelanjaan untuk membeli suatu barang. Dengan begitu dapat menghemat dana akomodasi yang tidak perlu mengantri dalam melakukan transaksi jual beli. Manfaat keberadaan online shop melalui internet yaitu sebagai media promosi suatu produk yang akan memberikan keuntungan bagi penjual karena produknya dikenal di seluruh dunia dan memberikan keuntungan bagi pembeli yang dapat lebih menghemat waktu, biaya, tenaga serta bisa dilakukan dimana saja dan kapan saja.

Online shop adalah pembelian suatu barang atau jasa dari mereka yang menjual barang atau jasa melalui internet dengan penjual dan pembeli tidak bertemu atau melalukan kontak fisik secara langsung, dimana penjual menampilkan produk yang ditawarkan melalui tampilan pada gambar yang diunggah di suatu website atau toko maya. Online shop serupa dengan pasar modern atau tradisional yang ada di dunia nyata, perbedaannnya hanya pada proses transaksi jual belinya yaitu dengan menggunakan jaringan internet yang memudahkan para pembeli melihat pilihan barang dan harga, cukup hanya membuka web online shop dengan menggunakan sambungan internet. Hal ini membuat banyak penjual online shop berlomba-lomba menawarkan produknya dengan berbagai cara yang menarik pelanggan untuk berbelanja. Berkembangnya online shop pun membuat banyaknya media sosial baru bermunculan yang akan mendukung kegiatan dari bisnis jual beli tersebut, salah satunya yang sedang booming adalah media sosial Instagram.

Instragram adalah sebuah aplikasi untuk berbagi foto maupun video di smartphone dengan berbasis sistem operasi Android, IOS dan Windows yang memungkinkan pengguna mengambil foto, mengambil video dan membagikannya lagi ke berbagai media sosial lain seperti Twitter, Facebook, dan lain-lain. Instagram dianggap lebih menarik daripada media sosial lainnya yang ada di Indonesia, khusunya pada kalangan remaja. Instagram biasa digunakan untuk berbagi foto, berbagi video, mencari informasi produk online shop, mencari hal-hal menarik dan lainlain. Setelah sukses menjadi aplikasi yang banyak diminati masyarakat, instagram dapat juga digunakan sebagai media pemasaran melalui foto produk yang diunggah oleh penjual. Melalui instagram juga akan mendapatkan banyak follower yang memudahkan pelanggan melihat produk yang dijual serta dapat memberi komentar secara langsung pada foto produk yang diinginkan. Dengan demikian instagram menjadi media sosial yang strategis bagi para pembisnis untuk memasarkan produknya dengan segala kemudahan yang ada.

Menurut kingpromosi.com terdapat enam urutan produk terlaris dan paling dicari di online shop Indonesia. Kedudukan dengan pencarian tertinggi adalah produk fashion, dengan urutan selanjutnya yaitu pencarian produk gadget, alat-alat elektronik, produk kecantikan, buku dan produk video game. Fashion merupakan produk yang paling banyak dicari karena kesibukan masyarakat yang padat, terutama yang berada di perkotaan membuat pelanggan ingin tetap tampil stylish dengan menggunakan cara praktis yaitu dengan membeli produk-produk fashion melalui online shop. Produk fashion ini pun sangat beragam seperti pakaian, tas, kacamata, sepatu, jam tangan, hingga 
bermacam-macam aksesoris lainnya yang dianggap dapat menunjang penampilan baik pria maupun wanita. Salah satu online shop yang menjual produk fashion khususnya pakaian wanita melalui instagram adalah Yellow Facy Jeans.

Yellow Facy Jeans merupakan online shop yang bergerak di bidang fashion dan didirikan berdasarkan perkembangan produk fashion terkini yang secara khusus melakukan jual beli melalui media sosial instagram. Yellow Facy Jeans berusia dua tahun sejak mulanya terjun memasuki dunia bisnis di instagram pada tahun 2016 dengan menawarkan berbagai produk terbaru khususnya bagi kalangan remaja wanita. Update koleksi Yellow Facy Jeans dilakukan hampir setiap minggu dengan mengunggah foto-foto produk terbaru di media sosial instagram. Yellow Facy Jeans ternyata banyak menarik minat masyarakat untuk melakukan pembelian, sehinga kini menjadi online shop yang cukup berkembang pesat. Berikut ini disajikan perbandingan data jumlah followers pada

Tabel 1 Perkembangan Yellow Facy Jeans Berdasarkan Jumlah Followers di Instagram Pada Tahun 2016-2017

\begin{tabular}{cc}
\hline Tahun & Jumlah Followers Instagram \\
\hline 2016 & 500 \\
2017 & 1500 \\
\hline
\end{tabular}

Sumber: Yellow Facy Jeans, 2018.

Pada tabel 1, telihat bahwa jumlah followers Yellow Facy Jeans di media sosial instagram mengalami kenaikan dari tahun 2016 sampai tahun 2017. Selain itu dapat dilihat juga bahwa pada tahun 2016, Yellow Facy Jeans masih belum memiliki banyak followers dikarenakan pada tahun 2106 merupakan tahun awal mulanya Yellow Facy Jeans didirikan. Kemudian pada tahun berikutnya, yaitu pada tahun 2107 mengalami peningkatan yang cukup drastis karena mulai banyak pengguna instagram yang mengetahui akun online shop milik Yellow Facy Jeans. Berdasarkan tabel di atas, dapat disimpulkan bahwa Yellow Facy Jeans mengalami pertumbuhan pesat dengan bertambahnya followers yang semakin banyak pertahunnya.

Jumlah followers yang tinggi, tidak memungkinkan adanya persaingan pada industri sejenis. Persaingan yang ketat dalam industri fashion, Yellow Facy Jeans harus menetapkan strategi pemasaran yang tepat sehingga dapat mencapai target yang diharapkan. Seperti salah satu strategi yang digunakan oleh Yellow Facy Jeans yaitu dengan melalukan kegiatan endorse, yaitu memberikan produk atau barang dari Yellow Facy Jeans secara gratis kepada artis yang memungkinkan namanya sudah terkenal. Kemudian artis tersebut meng-upload foto atau video dirinya bersama barang yang di-endorse di media sosial instagram. Dimana dengan kegiatan endorse, permintaan dari pelanggan terus meningkat hingga saat ini karena banyak pelanggan yang sudah percaya dan merasa puas.

Kepuasan pelanggan berasal dari suatu kondisi dimana pelanggan merasa puas terhadap suatu hasil dari persepsi pelanggan pada kinerja yang diharapkan. Puas atau tidaknya pelanggan merupakan respon yang ditunjukkan oleh pelanggan terhadap evaluasi dari ketidaksesuaian yang dapat dirasakan antara harapan sebelumnya dengan kinerja suatu produk 
atau jasa yang dirasakan setelah penggunaannya.

Faktor yang mempengaruhi terbentuknya kepercayaan adalah nilainilai, ketergantugan pada pihak lainnya, komunikasi yang terbuka dan teratur, serta berperilaku secara opportunitis, yaitu mengambil keuntungan dari peluang yang ada tanpa berpegang pada prinsip tertentu. Kepercayaan pada penjual diperngaruhi oleh keahlian daripada penjual itu sendiri. Kepercayaan terhadap online shop muncul karena pelanggan yakin bahwa online shop mengacu pada penilaian adanya mekanisme keamanan yang memadai. Kecenderungan masyarakat untuk berbelanja secara online mengurangi tingkat kewaspadaan yang terbukti dengan banyaknya kasus penipuan dengan modus online shopping, terumata disebabkan karena penjual dan pembeli tidak bertatap secara langsung. Dengan demikian, sistem kepercayaan menjadi modal utama dalam setiap transaksi jual beli online.

Tujuan penelitian adalah untuk mengetahui "Pengaruh Kualitas Layanan dan Kepercayaan Terhadap Kepuasan Pelanggan Produk Fashion Pada Online Shop Yellow Facy Jeans Melalui Media Sosial Instagram”.

\section{LANDASAN TEORI}

\section{Kualitas Layanan}

Menurut Tjiptono (2014), "Kualitas layanan adalah ukuran seberapa baik tingkat layanan yang mampu diberikan kepada pelanggan sesuai dengan ekspektasinya". Jika jasa atau layanan yang diterima atau dirasakan sesuai dengan harapan pelanggan, maka kualitas yang dihasilkan oleh jasa atau layanan dipersepsikan baik dan memuaskan. Apabila jasa atau layanan yang diterima mampu melampaui ekspektasi pelanggan, maka kualitas yang dihasilkan oleh jasa atau layanan dipersepsikan sebagai kualitas layanan yang unggul.

Menurut Kotler, et, al (2012), "Kualitas layanan adalah keutuhan dari ciri dan sifat suatu produk atau layanan". Sedangkan menurut Goeth dan Davis dalam Tjiptono (2012), "Kualitas layanan merupakan suatu kondisi yang berhubungan dengan produk, jasa, manusia, proses, dan lingkungan yang dapat memenuhi atau melebihi harapan pelanggan".

Ukuran sebuah kualitas layanan dapat diketahui dengan melakukan perbandingan antara persepsi pelanggan atas layanan yang nyata mereka terima atau peroleh dengan layanan yang sesungguhnya mereka harapkan atau inginkan terhadap atribut layanan suatu perusahaan. Hal-hal yang berhubungan dengan layanan yaitu faktor manusia yang memberikan pelayanan, fasilitas atau alat yang digunakan untuk memberikan layanan, mekanisme kerja yang digunakan dan sikap dari seseorang yang memberi layanan dan yang dilayani. Faktor utama dalam mempengaruhi kualitas layanan adalah layanan yang diharapkan oleh pelanggan serta pandangan masyarakat terhadap pelanggan itu sendiri. Nilai yang diciptakan kualitas layanan tergantung dari kemampuan perusahaan dan staffnya secara konsisten dalam memenuhi ekspektasi pelanggan.

Dari beberapa pengertian di atas maka dapat disimpulkan bahwa kualitas layanan adalah tingkat keunggulan yang diharapkan atau diinginkan oleh pelanggan serta pengendalian pada tingkat keunggulan tersebut yang menunjukkan kemampuannya untuk memuaskan kebutuhan dan keinginan pelanggan, baik yang nampak jelas maupun yang tersembunyi sesuai dengan ekspektasi pelanggan yang menilainya. 
Menurut Zeithaml, et, al (dalam Hardiansyah, 2011), "Kualitas layanan dapat diukur berdasarkan lima dimensi, yaitu berwujud (tangible), kehandalan (reliability), ketanggapan (responsiviness), jaminan (assurance) dan empati (emphaty)". Berikut pengertian dimensi kualitas layanan: a). Berwujud (Tangible); Tangible adalah wujud fisik secara nyata yang termasuk di dalamnya yaitu pegawai, peralatan, fasilitas, sarana informasi atau komunikasi. Tangible juga merupakan kedisiplinan pegawai, tampilan fisik saat melakukan pelayanan, peralatan, ketersediaan sarana-prasarana, kemudahan memperoleh atau melakukan komunikasi dan informasi. Menurut Tjiptono (2012), "Hal yang menyangkut tangible meliputi sumber daya manusia, penampilan fisik, peralatan atau perlengkapan, fasilitas layanan dan materi komunikasi perusahaan". Dimensi tangible terdiri dari atas: (1). Penampilan petugas atau aparatur dalam melayani semua pelanggan; (2). Kenyamanan pada tempat melakukan pelayanan; (3). Kemudahan yang didapatkan dalam melakukan proses pelayanan; (4). Kedisiplinan yang ditunjukkan oleh petugas atau aparatur dalam melakukan pelayanan; (5). Kemudahan pelanggan mengakses dalam permohonan pelayanan; (6). Penggunaan alat yang dapat membantu dalam pelayanan. b). Kehandalan (Reliability); Reliability adalah kemampuan suatu perusahaan dalam memberikan layanan yang telah dijanjikan secara akurat dan memuaskan. Selain itu, relaiability juga dapat meliputi kemampuan perusahaan untuk melaksanakan layanan yang dijanjikan, ketepatan dan keakuratan, metode pelayanan, kemampuan pegawai dalam memberikan solusi dan mengatasi masalah yang dihadapi serta kemampuan mengoperasionalkan berbagai peralatan pelayanan. Menurut Tjiptono (2012), "Reliability adalah kemampuan yang dapat dilakukan oleh perusahaan dalam menyampaikan layanan yang telah dijanjikan dengan akurat dan terpercaya". Dimensi reliability terdiri atas: (1). ecermatan petugas dalam melayani pelanggan; (2). Memiliki standar pelayanan yang jelas; (3). Kemampuan petugas atau aparatur dalam menggunakan alat bantu dalam proses pelayanan; (4). Keahlian petugas atau aparatur dalam menggunakan alat bantu dalam proses pelayanan. c). Ketanggapan (Responsiviness); Responsiviness adalah sejauh mana sebuah perusahaan dapat melihat kebutuhan dan keinginan pasar serta respon terhadap keluhan para pelanggan. "Responsiviness berhubungan dengan kesediaan dan kemampuan penyedia layanan dalam membantu para pelanggan serta menanggapi permintaan pelanggan dengan segera" (Tjiptono, 2012). Responsiviness merupakan salah satu dimensi paling dinamis. Salah satunya adalah keinginan karyawan dalam membantu dan memberikan layanan kepada para pelanggan dengan cepat. Dimensi responsiviness terdiri atas: (1). Menanggapi setiap pelanggan yang ingin mendapatkan pelayanan; (2). Petugas atau aparatur melakukan pelayanan dengan cepat; (3). Petugas atau aparatur melakukan pelayanan dengan tepat; (4). Petugas atau aparatur melakukan pelayanan dengan cermat; (5). Petugas atau aparatur melakukan pelayanan dengan waktu yang tepat. d). Jaminan (Assurance); Assurance merupakan dimensi yang berhubungan dengan kemampuan yang dimiliki oleh perusahaan dan perilaku karyawan dalam menumbuhkan rasa percaya dan yakin kepada pelanggannya. Menurut Tjiptono (2012), "Assurance berkenaan dengan pengetahuan dan kesopanan karyawan serta kemampuan yang dimiliki dalam menciptakan rasa percaya dan keyakinan pada pelanggan". Dimensi assurance terdiri atas: (1). Petugas atau aparatur memberikan jaminan tepat waktu dalam 
pelayanan; (2). Petugas atau aparatur memberikan jaminan biaya dalam pelayanan; (3). Petugas atau aparatur memberikan jaminan legalitas dalam pelayanan; (4). Petugas atau aparatur memberikan jaminan kepastian biaya dalam pelayanan. e). Empati (Emphaty); Emphaty adalah sifat dan kemampuan yang dimiliki perusahaan untuk memberikan perhatian penuh kepada pelanggan, memiliki komunikasi yang baik, memberikan kemudahan kontak yang dapat dihubungi dan memahami kebutuhan pelanggan secara individual. Secara umum, dimensi ini merupakan dimensi kurang penting di mata para pelanggan. Namun bagi kelompok pelanggan dengan kelas atas, dimensi ini dapat menjadi dimensi yang sangat penting. Menurut Tjiptono (2012), "Perusahaan harus memahami permasalahan para pelanggan dan bergerak untuk kepentingan pelanggan, memberikan layanan personal kepada pelanggan, serta memilih jam operasional yang sesuai". Dimensi emphaty terdiri atas: (1). Mengutamakan kepentingan masyarakat; (2). Petugas atau aparatur melayani dengan sikap ramah; (3). Petugas atau aparatur melayani dengan sopan santun; (4). Petugas atau aparatur melayani dengan tidak diskriminatif (membeda-bedakan); (5). Petugas atau aparatur melayani dan menghargai setiap pelanggan

Menurut Lupiyoadi dan Hamdani (2008), "Terdapat empat pengaruh atau peranan utama dari aspek pelanggan dalam mempengaruhi pelanggan lain”, diantaranya sebagai berikut: a). Contractors; Tamu berinteraksi dengan pelanggan secara langsung dalam frekuensi yang cukup sering dan sangat mempengaruhi keputusan pelanggan dalam melakukan suatu pembelian. b). Modifier; $\quad$ Tamu mempengaruhi pelanggan dan berhubungan dengan pelanggan lain tidak secara langsung tetapi masih dalam jangka waktu yang cukup sering. c). Influencer; Mempengaruhi pelanggan cukup hanya dengan membeli tetapi secara tidak langsung melakukan kontak dengan pembeli. d). Isolated; Tamu ikut serta dalam bauran pemasaran tetapi tidak secara langsung dan juga tidak sering bertemu dengan pelanggan. Partisipan yang berfungsi sebagai penyedia jasa dapat mempengaruhi kualitas jasa yang diberikan.

\section{Kepercayaan}

Kotler dan Keller (2016), "Kepercayaan adalah kesediaan perusahaan untuk mengendalikan para mitra bisnis. Kepercayaan tergantung pada beberapa faktor interpersonal maupun antar organisasi yang meliputi kompetensi perusahaan, integritas, kejujuran dan kebaikan".

Menurut Lau dan Lee dalam Tjiptono (2014), “Kepercayaaan pada sebuah merek tertentu merupakan aspek yang krusial dalam pembentukan kepuasan pelanggan yang dapat menciptakan loyalitas pelanggan, karena kepercayaan merupakan kesediaan pelanggan untuk mempercayai atau mengendalikan produk atau jasa dalam situasi beresiko karena adanya harapan bahwa produk atau jasa yang bersangkutan akan memberikan hasil yang positif".

Menurut Mayer et, al (Susanti dalam Cholichul, 2013), "Kepercayaan adalah sebagai kesediaan satu pihak dalam mempercayai pihak lain yang akan melakukan tindakan tertentu yang penting bagi pihak yang mempercayainya". Sedangkan menurut Mowen dan Minor (2012), menyatakan bahwa "Kepercayaan pelanggan adalah pengetahuan yang dimiliki pelanggan dan kesimpulan yang diberikan pelanggan mengenai objek, atribut, dan manfaatnya. Objek dapat meliputi produk, orang, perusahaan dan segala sesuatu dimana seseorang memiliki kepercayaan terhadap 
perilaku. Atribut merupakan fitur atau karakteristik yang dimiliki objek".

Kepercayaan akan membangun persepsi pelanggan, dimana merek memiliki integritas, kompetensi, benevolence dan lainnya yang akan mempengaruhi sikap dan perilaku. Kepercayaan merupakan salah satu pondasi utama di dalam dunia bisnis. Kepercayaan adalah kesediaan satu pihak dalam menerima resiko dari pihak lain berdasarkan keyakinan dan ekspektasi bahwa pihak lain akan memberikan perlakuan sesuai dengan apa yang diinginkan, meskipun kedua belah pihak tersebut belum mengenal antar satu dengan yang lain dan dapat menjalin hubungan dalam jangka panjang.

Dalam upaya peningkatan kepercayaan pelanggan dan pencapaian komitmen pelanggan serta terciptanya word of mouth, maka kepuasan pelanggan dapat terbentuk. Perusahaan menghasilkan barang dan jasa bertujuan untuk meningkatkan kepuasan pelanggan dan menciptakan word of mouth yang membuat pelanggan melakukan pembelian ulang dalam waktu jangka panjang. Oleh karena itu, kepercayaan pelanggan yang diberikan perusahaan diharapkan mampu mencapai serta memuaskan kebutuhan dan keinginan para pelanggan. Jika komitmen pelanggan tercapai, maka komunikasi word of mouth pun akan tercipta.

Dari pengertian di atas, dapat disimpulkan bahwa kepercayaan (trust) adalah rasa percaya pelanggan terhadap suatu perusahaan pada realibitas, durabilitas, dan integritas dalam hubungan dan keyakinan bahwa mitra yang dipercayainya mampu memberikan sesuai yang diharapkan serta harapan yang umumnya dimiliki seseorang seperti ucapan, janji ataupun pernyataan orang lain dapat dipercaya.

Menurut Gefen (Yee dan Faziharudean, 2010), "Kepercayaan terdiri dari tiga dimensi", diantaranya adalah: a). Integritas (Integrity); Integritas merupakan persepsi pelanggan yang menyatakan bahwa perusahaan akan menerapkan prinsip-prinsip yang dapat diterima meliputi penepatan janji, perilaku berdasarkan estetika dan jujur apa adanya. Integritas pada perusahaan tergantung konsistensi dari perusahaan di masa lalu, komunikasi kredibel atau tidaknya suatu perusahaan pada kelompok lain dan tindakan yang dijalankan oleh perusahaan sudah tepat. b). Kebaikan (Benevolence); Berdasarkan besarnya kepercayaan, kemitraan memiliki tujuan dan motivasi yang akan menjadi kelebihan untuk perusahaan lain pada saat kondisi yang baru muncul, yaitu kondisi dimana komitmen belum terbentuk. c). Kompetensi (Competence); Kompetensi merupakan kemampuan yang dimiliki perusahaan untuk mengatasi permasalahan yang dihadapi oleh pelanggan dan dapat memenuhi semua kebutuhannya. Kemampuan perusahaan mengacu pada keahlian, keterampilan dan karakteristik yang memungkinkan suatu kelompok memiliki pengaruh yang dominan.

Kepercayaan menjadi sangat penting dalam mencapai kepuasan pelanggan, meskipun pihak yang dapat dipercaya tidaklah mudah dan membutuhkan upaya bersama-sama dalam bekerja. Faktor-faktor yang mempengaruhi kepercayaan menurut Kurnia, Permas dan Rusli (2013), antara lain: a). Nilai merupakan hal mendasar dalam meningkatkan kepercayaan. Pihakpihak yang memiliki perilaku, tujuan dan kebijakan yang serupa akan mempengaruhi kemampuan dalam meningkatkan kepercayaan. b). Ketergantungan kepada pihak lain memungkinkan adanya kerentanan. Untuk dapat meminimalisir resiko pihak yang tidak percaya yaitu dengan membina hubungan baik yang dapat dipercaya. c). Komunikasi yang teratur dan terbuka. Komunikasi yang dijalankan 
guna menciptakan kepercayaan harus dilakukan secara teratur dan berkesinambungan, relevan serta tepat waktu. Komunikasi positif yang dilakukan pada masa lalu dapat menciptakan kepercayaan dan pada gilirannya menjadi komunikasi yang lebih baik lagi.

\section{Kepuasan Pelanggan}

Menurut Etta (2013), "Kepuasan atau ketidakpuasan pelanggan adalah perasaan senang atau kecewa seseorang yang berasal dari perbandingan antara kesan terhadap kinerja produk riil atau aktual dengan kinerja produk yang diharapkan". Sedangkan menurut Tjiptono (2012), "Kepuasan pelanggan merupakan konsep sentral dalam wacana bisnis dan manajemen. Konsekuensi pada kepuasan pelanggan sangatlah krusial bagi pelanggan, kalangan bisnis dan pemerintah. Peningkatan kepuasan pelanggan memiliki potensi yang mengarah pada pertumbuhan penjualan dalam jangka panjang maupun jangka pendek, serta pangsa pasar sebagai hasil pembelian ulang". Dalam setiap perusahaan, kepuasan pelanggan menjadi hal yang penting karena jika pelanggan merasa puas dengan layanan yang diberikan, maka posisi produk akan baik di pasar.

Kepuasan pelanggan menurut Kotler dalam Etta (2013), "Perasaan senang atau kecewa yang terbentuk setelah melakukan perbandingan antara presepsi atau kesan dengan kinerja suatu produk maupun harapan-harapannya. Menurut Kotler dalam Lupiyoadi (2013), "Kepuasan pelanggan merupakan tingkat perasaan dimana seseorang menyatakan hasil perbandingan atas kinerja produk layanan atau jasa yang diterima dengan yang diharapkan". Pencapaian kepuasan pelanggan dengan kualitas layanan dapat ditingkatkan melalui pendekatan berikut ini: a). Meminimalisir ketidakseimbangan yang terbentuk antara pihak manajemen dan pelanggan. b). Perusahaan harus memiliki komitmen bersama dalam menciptakan visi untuk perbaikan proses pelayanan yang meliputi perubahan cara pola berpikir, berperilaku, pengetahuan dan kemampuan dari segala sumber daya manusia yang ada. c). Memberikan peluang dalam menyampaikan keluhan pelanggan dengan menciptakan sistem kritik dan saran. d). Menerapkan dan mengembangkan partnership accountable, proaktif dan partnership saran. Perusahaan dapat menghubungi pelanggan setelah proses layanan terbentuk untuk mengetahui kepuasan yang dihasilkan dari harapan para pelanggan.

Berdasarkan pengertian di atas, dapat disimpulkan bahwa kepuasan pelanggan adalah perasaan senang ataupun kecewa seseorang terhadap suatu hal yang dianggap baik dan menyenangkan atau sesuatu yang dianggap mengecewakan yang berasal dari mengkonsumsi barang atau jasa setelah melakukan perbandingan apa yang diharapkan dengan apa yang diterima.

Pelanggan akan merasa puas apabila ekspektasinya dapat terpenuhi atau akan sangat puas bila harapan pelanggan terlampaui. Menurut Lupiyoadi (2011), "Terdapat empat dimensi utama kepuasan pelanggan", yaitu: a). Kualitas Produk (Product Quality); Pelanggan merasakan puas jika hasil suatu evaluasi menunjukkan bahwa produk atau barang yang dipakai berkualitas. "Produk dapat dikatakan berkualitas bila produk itu sendiri dapat mencukupi kebutuhannya" b). Harga (Price); Produk yang memiliki kualitas serupa namun menetapkan harga yang relatif lebih murah akan memberikan nilai yang lebih unggul di mata pelanggan. c). Kualitas pelayanan (Service Quality); Pelanggan akan merasa puas bila pelayanan yang diterima baik atau sesuai dengan yang diinginkan oleh 
pelanggan. d). Faktor emosional (Emotional Factors); Pelanggan merasa puas dan berkeyakinan bahwa orang lain akan merasa senang bila menggunakan produk atau barang dengan merek tertentu yang cenderung memiliki tingkat kepuasan yang lebih unggul. Kepuasan yang dihasilkan oleh pelanggan bukan hanya karena kualitas dari produk, namun sosial atau self esteem yang membuat pelanggan merasa puas.

Strategi dalam menciptakan kepuasan pelanggan merupakan strategi yang akan digunakan oleh perusahaan guna meraih dan meningkatkan kepuasan melalui peningkatan pangsa pasar, penjualan dan jumlah pelanggan. Menurut Tjiptono (2012), "Strategi kepuasan pelanggan yang dapat diterapkan pada perusahaan agar dapat meningkatkan kepuasan pelanggan" antara lain adalah: a). Relationship Marketing; Pada strategi ini, hubungan transaksi yang terjadi antara penyedia jasa dan pelanggan akan terus berlanjut dan tidak hanya berakhir setelah penjualan atau pelayanan telah selesai. Faktor yang digunakan guna menciptakan relationship marketing adalah diciptakannya customer database, dimana daftar nama pelanggan yang perlu dibina hubungannya dalam jangka panjang. Database tidak hanya berisikan nama pelanggan, namun dapat mencakup hal-hal penting lainnya seperti jumlah dan frekuensi pada pembelian. b). Strategi superior service; Perusahaan yang menerapkan strategi ini berusaha untuk menawarkan pelayanan yang lebih unggul dari para pesaingnya. Untuk mewujudkannya dibutuhkan dana yang cukup besar, kemampuan pada sumber daya manusia serta usaha yang gigih, maka perusahaan dengan pelayanan superior akan meraih laba dan tingkat pertumbuhan yang lebih besar dari para pesaingnya yang juga memberikan pelayanan yang unggul. c). Strategi unconditional; Pada strategi ini, komitmen untuk mengusung kepuasan pada pelanggan yang menjadi gilirannya akan menjadi sumber dinamisme dalam penyempurnaan kualitas jasa atau layanan dan kinerja pada perusahaan. Selain itu, peningkatan motivasi para karyawan guna mencapai tingkat kinerja yang lebih baik lagi dari sebelumnya. d). Strategi penanganan keluhan yang efektif; Pengendalian keluhan yang baik secara efektif dapat memberikan kesempatan untuk mengubah pelanggan yang tidak puas menjadi pelanggan yang puas atau bahkan dapat menjadi pelanggan pribadi. e). Strategi peningkatan kinerja perusahaan; Strategi peningkatan kinerja perusahaan merupakan penyempurnaan proses dan produk jasa melalui upaya perbaikan berkesinambungan, pengamatan serta pengukuran pada kepuasan pelanggan secara berkerkelanjutan, mengamalkan pendidikan dan pelatihan mengenai komunikasi serta membangun tim kerja lintas fungsional, sehingga diharapkan wawasan dan pengalaman karyawan dapat semakin luas. f). Quality function deployment; Quality function deployment adalah praktik untuk menyusun suatu proses sebagai respon terhadap kebutuhan pelanggan dan berusaha mengimplementasikan apa yang dibutuhkan pelanggan menjadi apa yang dihasilkan oleh perusahaan. Hal ini dijalankan dengan melibatkan pelanggan dalam proses peningkatan suatu produk termasuk jasa. Dengan begitu memungkinkan suatu perusahaan dapat mengutamakan kebutuhan pelanggan dan menemukan respon kebutuhan secara inovatif.

Menurut Tjiptono (2014), "Realisasi kepuasan pelanggan dapat dilakukan melalui perencanaan, pengimplementasian serta pengendalian program secara khusus yang berpotensi memberikan beberapa manfaat pokok", diantaranya adalah: a). Reaksi terhadap produsen berbiaya rendah; Fokus pada 
kepuasan pelanggan yang merupakan upaya mempertahankan pelanggan dalam rangka menghadapi para produsen dengan biaya rendah. b). Manfaat ekonomik retensi pelanggan' Berbagai studi menunjukkan bahwa mempertahankan dan memuaskan pelanggan jauh lebih murah dibandingkan upaya yang dilakukan secara konsisten dengan menarik pelanggan baru. c). Nilai kumulatif dan relasi berkelanjutan; Kepuasan pelanggan dapat menciptakan upaya dalam mempertahankan loyalitas pelanggan terhadap produk atau jasa perusahaan selama periode waktu yang cukup lama dapat menghasilkan antusias yang jauh lebih besar daripada pembelian secara individual. d). Daya persuasif word of mouth; Dalam banyak industri, pendapat atau opini dari teman maupun keluarga jauh lebih persuasif dan kredibel daripada melakukan iklan atau promosi. e). Reduksi sensitivitas harga; Pelanggan yang puas dan loyal terhadap sebuah perusahaan cenderung lebih jarang untuk melakukan penawaran harga untuk setiap pembelian individualnya, karena faktor kepercayaan (trust) telah terbentuk.

\section{METODE PENELITIAN}

Metode penelitian yang digunakan adalah dengan pendekatan Explanatory Analysis yaitu menjelaskan hubungan kausalistik antar variabel.

Populasi dalam penelitian ini adalah pelanggan Yellow Facy Jeans di Kecamatan Bekasi Timur. Metode sampel yang digunakan adalah nonprobability melalui prosedur quota sampling. Sugiyono (2016), "Quota sampling adalah teknik untuk menentukan sampel dari populasi yang mempunyai ciri-ciri tertentu sampai jumlah (kuota) yang diinginkan". Pengumpulan data dilakukan secara langsung pada unit sampling. Setelah kuota terpenuhi, pengumpulan data dihentikan. Maka sampel pada penelitian yang dilakukan selama 6 bulan, diperoleh sebanyak 120 pelanggan Yellow Facy Jeans di Kecamatan Bekasi Timur. Dari total 165 pelanggan, 5 pelanggan tidak memenuhi kriteria dan sisanya 40 pelanggan tidak menjawab pertanyaan kuesioner dengan lengkap, sehingga tidak dapat diuji.

Kemudian menganalisis hubungan dan pengaruh antara variabel bebas terhadap variabel terikat digunakan model-model kausalistik melalui analisis regresi dan korelasi baik secara bersamasama, sebelum dilakukan analisis terlebih dahulu dilakuan uji instrumen data.

\section{HASIL PENELITIAN DAN PEMBAHASAN}

\section{Uji Instrumen Data}

Berdasarkan penelitian pada bab sebelumnya dan dari data yang telah diperoleh, maka untuk dapat menentukan apakah variabel kualitas layanan dan kepercayaan dapat dijadikan pengukur terhadap kepuasan pelanggan dalam melakukan jual beli secara online di Yellow Facy Jeans. Namun sebelumnya data diolah terlebih dahulu dan dilakukan pengujian terhadap varibel yang digunakan yaitu kualitas layanan dan kepercayaan untuk mengetahui apakah data tersebut akurat dan dapat dipercaya. Dengan demikian hasil pengujian yang telah dilakukan dapat dilihat sebagai berikut:

\section{Uji Validitas}

Pengujian validitas ini dilakukan untuk menguji apakah tiap butir pernyataan telah mewakili indikator yang akan diteliti, persyaratan minimum untuk dapat dikatakan valid adalah $\mathrm{r}=0,30$. Jadi, apabila korelasi antara butir-butir item pernyataan dengan skor total kurang dari 0,30, maka butiran dalam instrumen tersebut dapat dikatakan tidak valid. Uji validitas dilakukan dengan melihat 
korelasi antara skor masing-masing item pernyataan dengan skor total.

Dari perhitungan koefisien korelasi skor tiap butir pernyataan instrument kualitas layanan dari 120 responden, dengan jumlah 15 pernyataan; instrumen kepercayaan 9 pernyataan dan instrumen kepuasan pelanggan 12 pernyataan dengan total skor setiap responden diperoleh hasil yang disajikan dalam tabel sebagai berikut:

Tabel-1 : Hasil Uji Validitas Instrumen Variabel

\begin{tabular}{|c|c|c|c|c|c|}
\hline \multirow[b]{2}{*}{ Pernyataan } & \multicolumn{3}{|c|}{ R Hitung } & \multirow[b]{2}{*}{ R Kritis } & \multirow[b]{2}{*}{ Kesimpulan } \\
\hline & $\begin{array}{l}\text { Kualitas } \\
\text { Layanan }\end{array}$ & Kepercayaan & $\begin{array}{l}\text { Kepuasan } \\
\text { Pelanggan }\end{array}$ & & \\
\hline Inst. 1 & 0.300 & 0.561 & 0.349 & 0.300 & Valid \\
\hline Inst. 2 & 0.355 & 0.535 & 0.338 & 0.300 & Valid \\
\hline Inst. 3 & 0.325 & 0.537 & 0.408 & 0.300 & Valid \\
\hline Inst. 4 & 0.310 & 0.514 & 0.469 & 0.300 & Valid \\
\hline Inst. 5 & 0.375 & 0.391 & 0.464 & 0.300 & Valid \\
\hline Inst. 6 & 0.401 & 0.478 & 0.354 & 0.300 & Valid \\
\hline Inst. 7 & 0.440 & 0.507 & 0.342 & 0.300 & Valid \\
\hline Inst. 8 & 0.419 & 0.570 & 0.415 & 0.300 & Valid \\
\hline Inst. 9 & 0.426 & 0.570 & 0.421 & 0.300 & Valid \\
\hline Inst. 10 & 0.335 & - & 0.326 & 0.300 & Valid \\
\hline Inst. 11 & 0.357 & - & 0.386 & 0.300 & Valid \\
\hline Inst. 12 & 0.345 & - & 0.415 & 0.300 & Valid \\
\hline Inst. 13 & 0.413 & - & - & 0.300 & Valid \\
\hline Inst. 14 & 0.367 & - & - & 0.300 & Valid \\
\hline Inst. 15 & 0.382 & - & - & 0.300 & Valid \\
\hline
\end{tabular}

Sumber : Data primer, 2018

Berdasarkan tabel-1, dapat dilihat dan disimpulkan bahwa dari semua butir pernyataan variabel kualitas layanan, kepercayaan dan kepuasan pelanggan hasilnya adalah valid.

\section{Uji Reliabilitas}

Pengujian reliabilitas ini dilakukan untuk menguji seberapa jauh hasil pengukuran yang dapat diandalkan secara konsisten. Pada tabel hasil pengujian reliabilitas berikut, diketahui bahwa semua variabel mempunyai alpha di atas
0,6 yang berarti bahwa semua variabel dalam penelitian ini dapat diandalkan.

Tabel- 2 : Hasil Uji Reliabilitas Variabel

\begin{tabular}{lcc}
\hline \multicolumn{1}{c}{ Variabel } & Cronbach's Alpha & Keterangan \\
\hline Kualitas Layanan & 0.670 & Reliabel \\
Kepercayaan & 0.718 & Reliabel \\
Kepuasan Pelanggan & 0.664 & Reliabel \\
\hline
\end{tabular}

Sumber: Hasil pengolahan data, 2018 
Berdasarkan tabel di atas, dapat dilihat dan disimpulkan bahwa nilai Cronbach's Alpha positif dimana lebih besar dari 0,6 yang merupakan batas minimal koefisien reliabilitas dapat dianggap baik. Dengan demikian, dikatakan bahwa pernyataan di atas reliabel

\section{Analisis Hasil Penelitian}

Tabel 3 : Pengaruh Kualitas Layanan dan Kepercayaan Terhadap Kepuasan Pelanggan Produk Produk Fashion Pada Online Shop "Yellow Facy Jeans" Melalui Media Sosial Instagram

\begin{tabular}{lccccc}
\hline \multicolumn{1}{c}{$\begin{array}{c}\text { Hubungan } \\
\text { Variabel }\end{array}$} & R Square & Konstanta & Koefisien & Sig. & $\boldsymbol{\alpha}$ \\
\cline { 2 - 6 } & & & 0.647 & & \\
$\begin{array}{l}\text { Kualitas } \\
\text { Layanan }\end{array}$ & 0.715 & 1.663 & & 0.000 & 0.05 \\
Kepercayaan & & & 0.171 & & \\
\hline
\end{tabular}

Pengujian Signifikansi

F hitung $>$ F Tabel $=146.540>3.074$

Keterangan : Variabel Kepuasan Pelanggan

Sumber: data diolah 2018

Berdasarkan hasil perhitungan tabel 3 , dapat diketahui bahwa nilai $\mathrm{R}$ square sebesar 0,715, sedangkan berdasarkan hasil perhitungan koefisien regresi secara simultan diperoleh persamaan regresi yaitu sebesar $\mathrm{Y}=1,663+0,647\left(\mathrm{X}_{1}\right)+$ $0,171 \quad\left(X_{2}\right)$. Dari persamaan regresi berganda tersebut, dapat diketahui arah hubungan yang dihasilkan variabel independen terhadap variabel dependennya dengan asumsi variabel lain konstan.

Nilai R square adalah sebesar 0,715 atau $71,5 \%$. Hal ini berarti bahwa variasi variabel dependen yang dapat dijelaskan oleh variabel independen adalah sebesar $71,5 \%$, sedangkan sisanya sebesar $28,5 \%$ dijelaskan oleh variabel lainnya yang tidak dimasukkan ke dalam model regresi dalam penelitian ini, sehingga dapat disimpulkan bahwa kualitas layanan dan kepercayaan berpengaruh sebesar 71,5\% terhadap kepuasan pelanggan, sedangkan sisanya sebesar $28,5 \%$ disumbangkan oleh variabel lain yang tidak diteliti.

Koefisien regresi kualitas layanan adalah sebesar 0,647. Hal ini berarti bahwa jika setiap penambahan 1 kali kualitas layanan, maka kepuasan pelanggan produk fashion pada online shop "Yellow Facy Jeans" melalui media sosial instagram akan meningkat sebesar 0,647 kali.

Koefisien regresi kepercayaan adalah sebesar 0,171. Hal ini berarti bahwa jika setiap penambahan 1 kali kepercayaan, maka kepuasan pelanggan produk fashion pada online shop "Yellow Facy Jeans" melalui media sosial instagram akan meningkat sebesar 0,171 kali.

Kedua variabel tersebut bertanda positif yang menunjukkan adanya hubungan signifikan dari variabel kualitas layanan dan kepercayaan terhadap kepuasan pelanggan produk fashion pada online shop "Yellow Facy Jeans" melalui media sosial instagram.

\section{Pembahasan}

Pengaruh Secara Simultan Kualitas Layanan dan Kepercayaan Terhadap Kepuasan Pelanggan

Berdasarkan pengujian yang telah dilakukan secara deskriptif, bahwa kepuasan pelanggan pada Yellow Facy Jeans dibentuk oleh kualitas layanan dan 
kepercayaan. Dimana dukungan terbesar terhadap variabel kualitas layanan melalui indikator Bukti Fisik (Tangible) yaitu Yellow Facy Jeans memiliki aplikasi yang cukup menarik. Indikator yang mendukung berikutnya Kehandalan (Realiability) yaitu Shopee memberikan layanan terbaik sesuai kebutuhan pelanggan. Indikator yang mendukung berikutnya Daya Tanggap (Responsiveness) yaitu kemampuan layanan Yellow Facy Jeans yang dapat dipercaya dalam menjaga keamanan pengemasan barang. Indikator yang mendukung berikutnya Jaminan (Assurance) yaitu adanya jaminan perlindungan dan keamanan yang diberikan Yellow Facy Jeans dalam pengiriman barang. Indikator yang mendukung berikutnya Empati (Empathy) yaitu Yellow Facy Jeans peduli akan keinginan pelanggan.

Kemudian dukungan terbesar yang diberikan variabel kepercayaan melalui indikator Integritas (Integrity) yaitu Yellow Facy Jeans akan memenuhi apa yang diharapkan oleh pelanggan. Indikator yang mendukung berikutnya Kebaikan (Benevolence) yaitu Yellow Facy Jeans meiliki keinginan untuk memberikan keuntungan bagi pelanggannya. Indikator yang mendukung berikutnya Kompetensi (Competence) yaitu Produk Yellow Facy Jeans lebih baik dan lebih terjangkau dibanding online shop lain. Sedangkan dukungan terbesar yang diberikan variabel kepuasan pelanggan melalui indikator Kualitas Produk (Product Quality) yaitu Yellow Facy Jeans memberikan layanan yang diinginkan pelanggan. Indikator yang mendukung berikutnya Harga (Price) yaitu Saya percaya Yellow Facy Jeans memberikan kepuasan dalam bertransaksi. Indikator yang mendukung berikutnya Kualitas Layanan (Service Quality) yaitu Yellow Facy Jeans mampu menjaga privasi pelanggan. Indikator yang mendukung berikutnya Faktor Emosional (Emotional Factors) yaitu Saya akan berbelanja di Yellow Facy Jeans dan melakukan pembelian ulang dalam jangka panjang.

Berdasarkan penelitian yang telah dilakukan bahwa kualitas layanan dan kepercayaan secara simultan berpengaruh yang signifikan terhadap kepuasan pelanggan, serta dapat disimpulkan dari nilai signifikansi bahwa hipotesis terbukti diterima.

\section{KESIMPULAN DAN SARAN}

\section{Kesimpulan}

Berdasarkan analisis data dan pengujian hipotesis yang telah dilakukan, maka hipotesis yang menyatakan bahwa kualitas layanan dan kepercayaan mempengaruhi kepuasan pelanggan pada Yellow Facy Jeans dapat diterima. Pernyatan ini didukung oleh hasil penelitian yang menyatakan bahwa terdapat pengaruh yang positif antara kualitas layanan dan kepercayaan terhadap kepuasan pelanggan Yellow Facy Jeans. Berdasarkan hasil analisis dan pembahasan, maka dapat ditarik kesimpulan sebagai berikut: 1). Kualitas layanan dan kepercayaan memiliki kontribusi terhadap kepuasan pelanggan. Dengan adanya kualitas layanan dan kepercayaan dapat memberikan pengaruh yang baik pada kepuasan pelanggan dari suatu produk. Variabel kualitas layanan dan kepercayaan dapat memberikan pengaruh positif kepada pelanggan sehingga menimbulkan kepuasan pelanggan. Temuan ini sejalan dengan pandangan teoritis dari peneliti terdahulu mengenai faktor-faktor yang mempengaruhi kepuasan pelanggan dimana variabel kualitas layanan dan kepercayaan berkontribusi terhadap kepuasan pelanggan. 2). Hasil pengujian uji t yang telah dilakukan bahwa kualitas layanan memiliki kontribusi terhadap kepuasan pelanggan. Kualitas layanan menjadi salah satu hal terpenting dari 
beberapa aktivitas pemasaran, sebab kualitas layanan terdiri dari lima dimensi utama yang terdiri dari, Keandalan (Reliability), Ketanggapan (Responsiveness), Jaminan (Assurance), Empati (Emphaty), Bukti Fisik (Tangible) yang diharapkan dapat membantu organisasi untuk mencapai tujuan suatu perusahaan dalam menciptakan kepuasan pelanggan. 3). Hasil pengujian uji t yang telah dilakukan bahwa kepercayaan memiliki kontribusi terhadap kepuasan pelanggan. Kepuasan pelanggan merupakan suatu kepercayaan dalam penggunaan produk yang meliputi rekomendasi. Dengan demikian hubungan yang diciptakan antara kepercayaan dengan kepuasan pelanggan yaitu apabila kepercayaan pelanggan terhadap suatu produk semakin tinggi, maka tingkat kepuasan pelanggan akan semakin tinggi.semakin tinggi kepercayaan pelanggan terhadap suatu produk, maka tingkat kepuasan pelanggan akan semakin tinggi pula. Peningkatan pada kepercayaan merupakan faktor penting yang memiliki kontribusi besar pada keseluruhan kepuasan pelanggan dikarenakan adanya hubungan pemasaran. Kepercayaan juga menjadi faktor dalam penentu kepuasan pelanggan..

\section{Saran}

Berdasarkan penelitian yang telah dilakukan, maka selanjutnya penulis ingin mengajukan beberapa saran yang sekiranya dapat menjadi acuan atau bahan pertimbangan serta masukan bagi perusahaan sebagai berikut: 1). Untuk meningkatkan kepuasan pelanggan, Yellow Facy Jeans harus memperbaiki kualitas layanannya baik sebelum dan sesudah terjadinya transaksi. Seperti kualitas produk yang sesuai dengan harapan pelanggan, bertanggung jawab jika terjadi kesalahan dalam pembelian, dan mampu berkomunikasi dengan baik karena kepuasan pelanggan terbukti dapat menciptakan loyalitas terhadap Yellow Facy Jeans serta pelanggan tidak segan memberikan referensi kepada orang lain. 2). Dalam peningkatan kualitas layanan, Yellow Facy Jeans harus terus memberikan pelayanan yang berkualitas yang nantinya akan menciptakan kepuasan pelanggan. Seperti peningkatan dalam pengambilan gambar produk, ketepatan pemberian layanan, dan kesesuaian representasi serta cepat dalam menanggapi keluhan pelanggan. 3). Untuk meningkatkan kepercayaan pelanggan, Yellow Facy Jeans dapat memberikan layanan yang terbaik, memberikan informasi produk jujur dan apa adanya, serta menjamin keberhasilan sistem pembayaran yang disediakan sehingga memudahkan pelanggan dalam melakukan pembayaran. Dengan adanya peningkatan kualitas layanan Yellow Facy Jeans, maka memungkinkan kepercayaan pelanggan akan semakin meningkat dan pelanggan akan lebih merasa puas berbelanja di Yellow Facy Jeans.

\section{DAFTAR PUSTAKA}

Etta, Mamang Sangadji \& Sopiah, 2013, Perilaku Pelanggan Pendekatan Praktis Disertai Ilmu Manajemen, Himpunan Jurnal Penelitian, Yogyakarta : Andi Offset

Gefen,D, Karahanna,E dan Straun,D. "Trust And Tam In Online Shopping: An Integrated Model". MIS Quarterly, Vol.27 No.1., March 2003. PP.51-90.

Ghozali, Imam, 2016, Aplikasi Analisis Multivariate Dengan Program IBM SPSS 23, Edisi Ke-8, Cetakan KeVIII, Semarang : Badan Penerbit Universitas Diponegoro

Goeth \& Davis, 2012, Quality Management, Fourth Edition, Cram101, Incorporated

Hardiansyah, 2011, Kualitas Pelayanan Publik, Yogyakarta : Gaya Media 
Kotler, Philip \& Armstrong, Gary, 2014, Principles of Marketing, $12^{\text {th }}$ Edition, Jilid I Terjemahan Bob Sabran, Jakarta : Erlangga

Kotler, Philip \& Keller, Kevin Lane, 2012, Prinsip-prinsip Pemasaran, Edisi ke 12, Jilid 1, Terjemahan Bob Sabran, Jakarta : Erlangga 2016, Marketing Management, $15^{\text {th }}$ Edition, Pearson Education, Inc

Kurnia, P.R, Achsan Permas \& Rusli, Martinus Sulistio, 2013, New Customer Relationship Management : Untuk Memenangkan Persaingan, Jakarta : Penerbit PPM

Lau, Geok Then and Sook Han Lee. (1999). "Consumers Trust in a Brand and the Link to Brand Loyalty". Journal of Market Focused Management.

Lupiyoadi, Rambat \& Hamdani, 2008, Manajemen Pemasaran Jasa, Jakarta : Salemba Empat

Mowen \& Minor, 2012, Perilaku Pelanggan, Dialih bahasakan oleh Dwi Kartika Yahya, Jakarta : Erlangga

Sugiyono. 2016. Statistika Untuk Penelitian. Bandung : Penerbit Alfabeta.

Susanti \& Cholichul, 2013, Kepercayaan Pelanggan dalam Melakukan Pembelian Gadget secara Online, Jurnal Psikologi dan Organisasi, Fakultas Psikologi Universitas Airlangga, Surabaya

Tjiptono, Fandy, 2014, Pemasaran Jasa, Edisi Ke-3, Yogyakarta : CV. Andi Offset

Umar, Husein, 2014, Metode Penelitian Untuk Skripsi dan Tesis Bisnis, Edisi-2, Cetakan Ke-13, Jakarta : Rajawali Pers

Yee, Yin \& T.M. Faziharudean, 2010, Factors Affecting Customer Loyalty of Using Internet Banking in Malaysia. Journal of Electronic
Banking Systems Faculty of Business and Accountancy, Universitas of Malaya

Zeithaml, V. A., \& Berry, L, 2011, The Service-Quality Puzzle. Business Horizons 